\title{
ADOPTION PROCEDURES
}

\section{Marie Arendt}

Adoption Secretary, Child Welfare

Society Johannesburg,

In collaboration with

Joyce Terry

Director, Child Welfare Society Pietermaritzburg

\section{OPSOMMING}

\section{AANNEMINGSPROSEDURES}

In Suid-Afrika word aannemings kragtens die Kinderwet gereël, en dit is belangrik dat dit deur goedgekeurde, ge-akkrediteerde instansies onderneem word om te verseker dat professionele vaardighede gebruik word en dat standaarde van diens aan die kind, die biologiese ouers en die aannemende ouers gehandhaaf word. Instansies wat hierdie diens lewer, doen ook beroep op geskikte mediese en ander konsultante, en bied ook aan sulke fasiliteite soos tehuise vir ongehude moeders, en kinderhuise of pleegouers wat miskien voor aannemingsplasing nodig mag wees. Dit is nie raadsaam dat enige indiwidu aannemingswerk sal aandurf nie. Aannemingswerk en die versorging van die ongehude moeder verg ook streng vertroulikheid.

Aangesien die kinders van ongehude moeders die mees waarskynlikste beskikbaar is vir aanneming, is dit in die gebied van die versorging van die ongehude moeder dat die maatskaplike werker en die vroedvrou baie nou kan saamwerk om 'n diens aan hulle kliënt/pasiënt te lewer en om onnodige lyding te voorkom. Die maatskaplike werker en die vroedvrou moet mekaar se rolle verstaan en nie op die ander se terrein inmeng nie. Die rol van die maatskaplike werker is om die ongehude moeder te help om tot 'n besluit te kom oor haar baba se toekoms, en in dié traumatiese tyd het sy professionele bystand nodig. Alhoewel die verpleegpersoneel baie versigtig moet wees om nie subjektief te wees of 'n invloed uit te oefen op die moeder nie, en ook nie emosioneel betrokke moet raak nie, kan hulle tog simpatiek aanluister en kan hulle ook vir die baba die liefdevolle sorg gee wat elke baba van geboorte af net so nodig het soos voeding en fisiese sorg.

Die keuring van geskikte aannemende ouers, en die plasing van die baba by die ouers wat vir hom die beste gesinslewe en liefde kan gee, is verdere ingewikkelde prosesse. Die vereistes van die Kinderwet moet sorgvuldig nagekom word, en aannemende ouers word aangemoedig om kontak met die aannemingsinstansie te behou sodat hulp aan hulle verleen kan word indien dit nodig is in die aanpassingsproses en die vervulling van die nuwe ouerlike rol.

$\mathbf{I}^{\mathrm{n}}$ early Eastern Greek and Roman civilisations, a childless couple adopted a child to provide a direct heir or to perpetuate domestic ancestral worship, and in later centuries adoption was used to solve the problem of illegitimacy. Although the child often benefitted from adoption, it was used primarily as a means of giving a child to a family in the interests of the adults involved. Today, adoption is still used to smooth problems of rights and inheritance of the child, but it has also become, much more, a way of giving a family to a child who needs substitute parents from whom he can receive the love and nurture which are so necessary for his full development.
In South Africa, adoption is arranged in terms of the Children's Act. There are eight child welfare societies, affiliated to the South African National Council for Child and Family Welfare, which are accredited to do non-disclosure adoptions. Accreditation helps to ensure that the service is given by skilled practitioners, and is renewed every two years. Adoption is a responsibility shared between experienced social workers, committee and consultants, including medical advisers. It is a highly skilled, specialised practice within an agency setting, which also utilises agency resources such as residential care for unmarried mothers, a children's home for foster parents for placement of babies pending 
adoption, and it is unwise for any individual to risk undertaking independent adoption work.

Adoption also requires a high standard of confidentiality from all who are involved in the process itself, or who care for the unmarried mother in a home or hospital setting. It is a sensitive area for all parties in the adoption, and there are many delicate relationships and adjusıments: careless talk can cost the emotional balance and the lives of clients/patients. Although adoption is primarily for the benefit of the child, it is also important to consider the rights and the interests of the biological parents and the adoptive parents.

As in most Western countries, there is a greater demand in South Africa than there are children available for adoption. Since the children most likely to need adoption are those born of unmarried mothers, it is in the field of care for the unmarried mother that the professional skills of the social worker and the midwives can mesh, through communication, consultation and co-operation, to help their client and to achieve their common goal of reducing human suffering. For this reason, it is as well to consider the unmarried mother and her care in more detail than other aspects of adoption which do not also involve the midwife to a great extent.

\section{COUNSELLING AND COMMUNICATION}

More often than not, when an unmarried mother is admitted to the midwifery unit in labour, she will already have an established relationship with the social worker, who will have been able to pinpoint for the pregnant girl what alternatives are open to her in making a decision about her future and that of her child. The social worker will also have been able to share with her client what the implications of each choice might well be.

In an article of this nature one cannot look in depth at all that is involved in each of these choices. One thing is certain, however - there is no easy way, and there will be losses and gains whatever the mother's decision. But it is important to remember that in good social work practice, no mother (whether unmarried, widow, divorced or a married woman) is ever pressurised. The social worker's role is one of helping and enabling the mother to make a decision that she can honour, and then to support her in that. This service applies to all parents who face the possibility of adoption of their children.

The midwife's patient comes to the hospital, not only with a whole network of relationships with family, friends, and the father of the child, but she also knows the social worker, whose task it is to understand the implications of the other relationships. Very clearly, then, when it comes to counsel and support regarding the mother's past and future, this is the social worker's territory, but she shares the present with the midwife who is caring lor her patient as a total person in the labour, delivery and post-delivery period.
It is in this phase that there must be easy communication between the social worker and midwife, and a clear definition of their respective roles and responsibilities in caring for the patient/client. Obviously the management of the labour and the delivery are exclusively the responsibility of the medical and nursing staff, but where there is free access to the labour and sometimes the delivery ward and if there is no close relative or friend available, it is the social worker who can play a supportive role, and her presence in the third stage of labour, after the crisis and climax of the birth and everyone else has gone, can be very reassuring to the patient.

Sharing the labour and birth experience helps the social worker afterwards, when she helps the mother work through her feelings of guilt, remorse and depression that are inevitably associated with the aftermath of the birth of the baby which she has already decided to offer for adoption. At this stage the mother will often seek advice from anyone who is prepared to give it, and the nursing staff can provide comfort and listen to her, and should advise the social worker when they become aware that the mother is troubled. They should not advise or influence the mother, who should also be protected from outside visitors, many of whom express their personal feelings and add to the uncertainty and sense of insecurity which the mother is experiencing. Young, impressionable nurses should guard against becoming emotionally involved with the mother and/or baby and against identifying themselves with the mother's problems.

Whatever way it is viewed, this is a traumatic situation, and the social worker is trying to help the mother mourn her loss with caring support, and to come to terms with relinquishing her child. There is no easy way and unskilled, subjective intervention at this stage may well be damaging to a mother's adjustment.

The unmarried mother who is making her baby available for adoption may need to see her baby in order to reassure herself that it is in fact a normal, healthy child, able to be loved and mothered by someone else, but this should be done in consultation with the social workers. There can be no hard-and-fast rule about discouraging the unmarried mother who is relinquishing the baby for adoption, from cuddling and fondling the baby, on the grounds that this is the beginning of bonding and forms a relationship which the mother finds extremely difficult to break. So much depends on the individual mother. Each mother is unique. Some will see the baby once, perhaps when they deliver, or briefly in the nursery, or before they leave the hospital. Others will feel a need to visit the nursery more often and perhaps spend time with the baby. Some, according to their maturity, will wish to hold, feed and even begin to bond with the baby. Throughout this whole process the social worker is on call and open to the needs of her client. Admittedly coming and going to and from the 
nursery impinge on hospital routine and regulations but no one must underestimate what it means to give a baby for adoption.

If a mother looks at her child with apparent detachment, it is because she has come to terms with the fact that somebody else will mother her child. If she weeps bitterly it is because she needs to do this. At least she knows what her child is like: otherwise she goes through a pregnancy of forty weeks and a delivery and never knows why. The findings of long experience: where a mother has seen her child as a reality, in the long term she makes a much better adjustment than if she has not.

And what of the baby, who needs cuddling and fondling and being spoken to as much as he requires physical care and nutrition? The nursing staff can play a very important role in compensating the baby by giving him special loving care in this vital early stage of his development before he leaves the hospital.

If the child is born with an abnormality, the extent and implications of this should be discussed with the mother by the relevant medical advisers, and the need for genetic counselling - if necessary - should also be discussed with her. Since it is in the best interests of the child that the adoptive parents are given correct information regarding his medical history, it is imporiant that the medical forms made available by the adoption society should be completed as accurately and fully as possible by the appropriate medical and nursing staff of the hospital where the baby is born.

Although each baby placed for adoption by an accredited adoption agency is assessed by a paediatrician of the medical advisory panel and a preliminary certificate completed, the midwife has a responsibility to ensure placement from the hospital as soon as possible. Keeping records, sending off blood and urine specimens can be expedited and rapid results obtained. It is the midwife who advises the social worker when a baby is ready for placement.

Legal consent to adoption can be given only after the birth of the child, and both parents (or the mother alone if she is unmarried) must sign consent in the presence of a Commissioner of Child Welfare. Adoptions may be 'disclosed' or 'non-disclosed', and it is in the latter case that a sworn statement has to be signed by the parent(s) to the effect that they are giving the child voluntarily, to persons unknown to them, and in the realisation that they are not entitled ever to find out where the child is (hence once again the need for confidentiality in adoptions). However, parental rights and responsibilities extend till the day that an Order of Adoption is granted to the couple who have adopted the child.

\section{THE SELECTION PROCESS}

In order to find the right parents for any child, a process of selection is necessary, which means predicting a couple's ability to accept, to love and to cherish a child not born to them. Childless couples obviously have not had the opportunity to demonstrate their capacity to nurture a child, but even for couples who have demonstrated this ability, each child is an individual and eacl new addition changes the family constellation. No selection can be infallible, but the lask of the adoption society is to select the most appropriate home from those available.

Screening eligible parents, and indeed tentative matching of expected babies, has usually been done before the baby has been born.

There are two stages in the screening process: the first is to determine whether the applicants are eligible in terms of the Act and the adoption society's requirements, and the second is their suitability as adoptive parents.

The study as to the eligibility and suitability of adoptive parents consists of several interviews, a visit to their home, and group discussions with other applicant adopters. Quite a number of applicants eliminate themselves after these meetings. References and a medical report on health and fertility of both applicants are required.

Concerning eligibility, the Act lays down a minimum age of 25 years for adoptive parents, and the Johannesburg Child Welfare Society, for instance, requires the ages to be within the span which is normal for natural parenthood, i.e. the female should be under 38 and the male not much over 40 . Although single persons may adopt, the object of adoption is to offer a child a normal home: therefore a society would not usually consider single persons for non-disclosure adoption, but special circumstances such as blood relationship could be considered. The society usually prefers couples who have been married for a minimum of say, three years, and because of the demand, it may restrict acceptance to a couple who for medical reasons have no children or only one child.

In assessing suitability, the agency also takes into account such factors as: motivation to adopt (the importance of assessing the true motivation cannot be too strongly emphasised, since a danger area could be an effort to cement a shaky marriage by bringing a child into their lives, and a desperate need for a child is also a risk, as this could be a neurotic symptom): infertility and childnessness (have they come to terms with their 
disappointment over childlessness in an emotionally mature way, or does the one blame the other? Are they ready to obtain medical advice and to accept treatment for their infertility?): marital relationship; emotional maturity: wider family and social relationships: financial security: and, very important, their attitudes towards adoption and towards unmarried parenthood.

The final decision regarding eligibility is taken at committee level, based on the findings of a medical advisory panel, confidential references, adoption workers' reports, as well as psychological assessments where necessary. Applicants are informed in writing of the Conmittee's decision and if accepted, their name is placed on a waiting list until a suitable child becomes available for them.

Matching the right parents for the child is the next stage in the process, and the right parents for the child will be those into whose home the child can fit most easily, and who will be able to meet his particular needs. Their suitability for this child, rather than their position on a waiting list, is the deciding factor.

The legal criteria for matching are set out in Section $35(2)$ of the Children's Act. The specific features of the respective backgrounds that must be taken into account are nationality, ethnological grouping, religion and culture, and in the case of the child these are determined by his parentage - in the case of a child born outside marriage, by that of his biological mother. In view of the outrage sometimes expressed overseas over efforts to encourage inter-country adoption (particularly from Asian countries) and the doubts expressed about the children's integration into foreign backgrounds, it is worthwhile to note that adoption of a South African child by a non-South African is not possible.

The likeness in physical characteristics is taken into consideration in matching, as it may help in the integration of the child into the adoptive family, and an assessment of the child's intellectual potential is also made. In the case of a newborn baby this is done according to the educational standard of the biologival parents, but such an assessment can only be a rough guide. The selected parents are given an opportunity of taking part in the selection by giving them some relevant background information on the child, as well as showing them the child before a final decision is taken. The adoption worker has to be on the alert and at this stage will assess whether the placement is serving the best interests of the child.
In the event of parents refusing a child, it is important to assess whether their difficulty lies in accepting this particular child, or whether they have doubts about adoption as such.

The newborn baby is only offered to applicants after the mother has given consent to adoption and the paediatrician acting for the adoption society has passed the baby as fit for adoption, and he is only placed after the Commissioner of Child Welfare has approved of the placement. The Commissioner has to be satisfied that the society has complied with the requirements of the Act in the placement. There should be no unnecessary delay in placing any child, but particularly in the case of the newborn baby, as ideally every infant should have continuous maternal care. Apart from the fact that maternal deprivation is reduced by swift placement, the adoptive parents are also given an opportunity of becoming parents at a time which is as near as possible to natural parenthood. The biological mother is also better able to make a new adjustment once she knows that her child has been suitably placed with parents. The adoption societies therefore aim at placing the babies in adoption as soon as possible, but it is sometimes necessary to defer placement if there are any doubts about the baby's health or development.

The contact maintained with adoptive parents after placement is limited, but valuable. Immediately after placement, visits are necessary and a further report has to be submitted to the Commissioner of Child Welfare before the adoption is finalised. The object of the visits is also to assist the adoptive parents in their adjustment to parenthood. Conflicts about their ability to love this child as their own may arise, and if they can be reassured that they are not unique in their feeling, it could remove guilt which they might have experienced. Their problems may, however, occur much later, and parents are encouraged to maintain contact with the society to enable it to assist them where possible.

Adoption is easily criticized, and perhaps also idealised. Parents often fail in their role as parents, but if they happen to be adoptive parents, adoption is blamed.

It is difficult to predict, during the screening process, how satisfactory the adjustment between the adoptive parents and the child will be. Adoption workers cannot claim that they have all the knowledge to identify the potential successful adoptive parents, and problems can be expected to occur in the adjustment process. Therefore after-care is an essential aspect of an adoption service, and group discussions with other adoptive parents are very helpful. 